\title{
Racial Discipline Disproportionality in Montessori and Traditional Public Schools: A Comparative Study Using the Relative Rate Index
}

\author{
Katie E. Brown† and Aimy S. L. Steele \\ University of North Carolina at Charlotte \\ Acknowledgement \\ This study was aided by a public Montessori school database created by sociologist Mira Debs. The authors \\ gratefully acknowledge this contribution.
}

Keywords. discipline, racial discipline disproportionality, Montessori, suspension

\begin{abstract}
Research from the past 40 years indicates that Black students in primary and secondary school settings are subjected to exclusionary discipline, including suspension and expulsion, at rates two to three times higher than their White peers (Children's Defense Fund, 1975; Skiba, Michael, Nardo, \& Peterson, 2002). Although this phenomenon has been studied extensively in traditional public schools, rates of racially disproportionate discipline in public Montessori schools have not been examined. The purpose of this study is to examine racial discipline disproportionality in Montessori public elementary schools as compared to traditional elementary schools. The Relative Rate Index (RRI) is used as a measure of racially disproportionate use of out-of-school suspensions (OSS) (Tobin \& Vincent, 2011). Suspension data from the 2011-2012 Office of Civil Rights Data Collection (n.d.) was used to generate RRIs for Montessori and traditional elementary schools in a large urban district in the southeastern United States. While statistically significant levels of racial discipline disproportionality are found in both the Montessori and traditional schools, the effect is substantially less pronounced in Montessori settings. These findings suggest that Montessori schools are not immune to racially disproportionate discipline and should work to incorporate more culturally responsive classroom management techniques. Conversely, the lower levels of racially disproportionate discipline in the Montessori schools suggest that further study of discipline and classroom management in Montessori environments may provide lessons for traditional schools to promote equitable discipline.
\end{abstract}

Discipline is not a term that often appears in Montessori literature. Montessorians discuss behavioral issues like grace and courtesy, self-control, and normalization, but discipline, as the term is used by mainstream educators, is rarely discussed. In traditional public schools, however, exclusionary discipline, including suspension and expulsion, is a critical issue. In the 2010-2011 academic year, 3.45 million children in pre-K through twelfth grade were suspended from American public schools at least once (U. S. Department of Education Office of Civil Rights, 2014). These students missed critical 
opportunities to learn and were less likely to graduate from high school and enroll in college than their peers who were never suspended. Furthermore, the phenomenon of racial discipline disproportionality in urban schools has been of special concern to researchers over the last 40 years (Children's Defense Fund, 1975; Lewis, Chambers, \& Butler, 2012; Skiba et al., 2002).

Discipline disproportionality refers to the over- or underrepresentation of certain groups in office disciplinary referrals, suspension, and/or expulsion (Skiba, 2005; Vincent, Tobin, Hawken, \& Frank, 2012). Previous studies indicate that students of color are two to three times more likely to be suspended or expelled than White students (Children's Defense Fund, 1975; Wallace, Goodkind, Wallace, \& Bachman, 2008), even though there is no evidence to suggest that these students misbehave more (Skiba et al., 2002). Black males experience the highest levels of discipline disproportionality; Black males are 3.3 times more likely to be suspended or expelled than White males (Wallace et al., 2008).

As Montessori programs continue to expand in the public sector, research increasingly has focused on various academic (Dohrmann, Nishida, Gartner, Lipsky, \& Grimm, 2007; Lillard \& Else-Quest, 2006) and social-emotional (Rathunde \& Csikszentmihalyi, 2005) outcomes of the Montessori Method that could improve American public education. One area that remains underresearched, however, is discipline in public Montessori programs - specifically, racially disproportionate disciplinary sanctions. The research question guiding this study is: Do public Montessori elementary schools exhibit different levels of racially disproportionate suspensions for Black students than comparable, traditional public elementary schools? Data from the U. S. Department of Education Office of Civil Rights (n.d.) have been compiled to generate a Relative Rate Index (RRI), or measure of racially disproportionate discipline, for Montessori and traditional elementary schools in a large, urban school district in the Southeast.

\section{Literature Review}

\section{Racial Discipline Disproportionality}

While out-of-school suspension (OSS) is commonplace, not all students are at equal risk of being suspended. Students of color are referred, suspended, and expelled at rates far higher than White students (Kaufman et al., 2010; KewalRamani, Gilbertson, Fox, \& Provasnik, 2007; Krezmien, Leone, \& Achilles, 2006; Skiba et al., 2011; Skiba, Peterson, \& Williams, 1997; Vincent, Swain-Bradway, Tobin, \& May, 2011; Vincent et al., 2012). Since the Children's Defense Fund initially raised the issue in 1975, subsequent studies have confirmed that exclusionary discipline practices like suspension and expulsion are disproportionately meted out to Black, Latino, and Native American students. Black students are more likely to be suspended in pre-K-12 school settings than any other racial group (Children's Defense Fund of Ohio, 2012); Black students are suspended at rates two to three times higher than their White peers (Skiba et al., 2002; Wallace et al., 2008). Skiba et al. (2002) clearly demonstrated that this suspension rate is not because Black students misbehave more than White students. Even when accused of the same offenses, Black students receive harsher punishments than White students (Lewis, Butler, Bonner, \& Joubert, 2010). Black students are also more likely to be disciplined for subjective offenses that rely on the judgment of teachers and administrators, like defiance or disrespect, especially at the secondary-school level (Skiba et al., 2002). Shollenberger (2015) illuminated the impact of racial discipline disproportionality with data from the National Longitudinal Survey of Youth. Of the 9,000 students aged 12 to 16 surveyed, $35 \%$ had experienced at least one suspension, while $44 \%$ of boys had been suspended compared to about $25 \%$ of girls. Nearly $67 \%$ of Black boys had been suspended, compared to $38 \%$ of White boys. Although race is the strongest nonbehavioral predictor of suspension, other contributing factors include administrator attitudes towards discipline, proportion of Black students (Skiba et al., 2015), and teacher and school quality (Cartledge, Gibson, \& Keynes, 2012). Interestingly, a recent study by Skiba et al. (2015) found that the proportion of students qualifying for free or reduced lunch was not a significant predictor of OSS in pre-K-12 school settings, although findings from Cartledge et al. (2012) contradict this information. Social scientists and educational researchers alike have concluded that Black and Latino 
students experience less favorable disciplinary consequences (Lewis et al., 2010) and academic outcomes in the public school system than their White peers (Vincent et al., 2012).

Although much of the literature on exclusionary discipline and disproportionality focuses on secondary-school settings (Bradshaw, Mitchell, O'Brennan, \& Leaf, 2010), these phenomena have been observed at the elementary level as well. Shollenberger (2015) found that more Black boys were suspended prior to the fourth grade than any other demographic. Butler, Lewis, Moore, and Scott (2012) documented the overrepresentation of Black male elementary school students in suspensions. They also found that race was a significant predictor of the length of suspension a student received, with students of color receiving longer suspensions than White students. Interestingly, these authors also found that OSS was employed more at the elementary level than at the secondary level, possibly because elementary school teachers have fewer alternatives for removing students deemed disruptive from the classroom (Butler et al., 2012). Although these authors recognized the need for additional research on exclusionary discipline and discipline disproportionality at the elementary level, they found it "reasonable to conclude that exclusionary discipline practices in secondary school are just as severe in elementary school, particularly for African Americans" (Butler et al., 2012, p. 20).

Though a staggering body of literature has been devoted to documenting racial discipline disproportionality, scholars have not reached consensus on specific causes or best remedies for inequitable discipline. Restorative justice (Gonzalez, 2015), Positive Behavioral Interventions and Supports (PBIS) (Vincent, Sprague, Pavel, Tobin, \& Gau, 2015), and student threat assessment (Cornell \& Lovegrove, 2015) have been proposed as tactics with potential to address the problem. Alternately, Weinstein, Curran, and Tomlinson-Clarke (2003) suggested that racial discipline disproportionality is partly attributable to teachers' lack of cultural awareness about the diverse students found in urban public schools.

\section{Negative Effects of Out-of-School Suspension}

Research shows that while used frequently as a disciplinary punishment, suspension does not correct behaviors of those suspended (Skiba, 2005). Suspensions from school can lead to repeat offenses, elevated dropout rate, and juvenile incarceration (Skiba, 2005). Out-of-school suspensions have been linked to low academic achievement as measured by state accountability tests (Vincent et al., 2012). The instructional time that students lose when suspended translates to reduced opportunities to learn and decreased academic achievement (Lewis et al., 2010). Several authors have highlighted the link between the so-called "achievement gap" and these racial disparities in discipline (Lee, 2002; Lee, Grigg, \& Donahue, 2007; Vincent et al., 2012). The term achievement gap is controversial because it perpetuates a deficit orientation toward students of color; some scholars have argued that the term opportunity gap is more appropriate (Flores, 2007). Indeed, racially disparate use of exclusionary discipline, like suspension and expulsion, does result in unequal opportunities to learn. Gregory, Skiba, and Noguera (2010) even refer to the achievement gap and the "discipline gap" as "two sides of the same coin" (p. 59). Though some scholars have begun to advocate for alternatives to suspension, such as restorative justice (Gonzalez, 2015) or PBIS (Vincent et al., 2015), out-of-school suspension remains a widespread school response to student misbehavior.

Reducing exclusionary discipline is paramount because suspension and expulsion are strongly associated with future criminal sanctions. The school-to-prison pipeline refers to the trend where students are "funneled out of public schools and into the criminal justice systems" (Wald \& Losen, 2003, p. 53). Overwhelmingly, the data show that the more often students are suspended and the earlier in the school career suspension occurs, particularly in the elementary and primary years, the more likely they are to be referred to the juvenile justice system and face jail or prison time (Shollenberger, 2015). The overrepresentation of Black students in school disciplinary sanctions bears a strong resemblance to the overrepresentation of Black males in the U.S. penal system (Wacquant, 2000). In fact, for every one time a minority child is suspended, he or she is $50 \%$ more likely to go to prison one day (James, 2014). 
According to Christle, Jolivette, and Nelson (2005), "the majority of court-involved youth have experienced academic failure, school exclusion and dropout" (p. 71).

Another aspect of the school-to-prison pipeline is the increased criminalization of school misbehavior. Although zero tolerance policies were initially established over 25 years ago to address the issues of drugs and guns in schools (Skiba \& Rausch, 2006), they have since evolved into a punitive system of predetermined consequences that mandates severe punishments even for infractions unrelated to drugs or weapons. Police officers and security guards constitute an increasing presence in schools and lead the way in guiding students toward the prison track as students are criminalized for discipline that should be handled at the school level (American Civil Liberties Union, n.d.). Most vulnerable to these types of practices are students of color, particularly Blacks and Latinos.

Further, an increasing number of schools have adopted the use of surveillance strategies once reserved for the criminal justice system (Hirschfield, 2010). Johnson, Boyden, and Pittz (2001) argued that the balance of school and the justice system is affected by the use of security technologies, security personnel, and profiling in high-minority, high-poverty school districts. With increased reliance on these surveillance tools, there has been a corresponding increase in referrals to the juvenile justice system for cases that used to be handled at the school level and that were not considered violent infractions (American Psychological Association Zero Tolerance Task Force, 2008). When looking at disciplinary disproportionality, the evidence clearly indicates that the higher the disproportionality among Black and Latino students in secondary schools, the higher the rate of imprisonment for these students (Vincent et al., 2012).

\section{Montessori, Behavior, and Discipline}

While there is a dearth of empirical research on exclusionary discipline in Montessori schools, there are reasons to hypothesize that the Montessori Method may reduce the need for such measures. The student-centered nature of the Montessori approach results in high levels of student engagement (Lillard, 2005), which has been linked to lower levels of student disruption and misbehavior (Klem \& Connell, 2004). Montessori has been shown to facilitate the development of self-regulation in elementary-aged children (Ervin, Wash, \& Mecca, 2010), which may also reduce misbehavior and disruption. Castellanos (2002) found that Montessori elementary students in private schools exhibited significantly less aggression than their peers in other private schools. The multiage nature of the Montessori classroom also creates continuity of classroom culture and climate from year to year; older students impart classroom norms and expectations to the new students (Lillard, 2005). Byun, Blair, and Pate (2013) found that students in a Montessori preschool classroom were less sedentary than their peers in a traditional preschool setting. The freedom of motion allowed in the Montessori classroom may also help prevent disciplinary sanctions for more active children.

Lastly, the research on looping (having the same teacher for two or more consecutive years) suggests that this practice can reduce and prevent disciplinary problems. Montessori is not looping in the strictest sense (Lindsay, Irving, Tanner, \& Underdue, 2008) since the cohort changes each year as older students move up and younger students move in. Nonetheless, having the same teacher for multiple years allows students to develop deeper and closer relationships with teachers (Lindsay et al., 2008; Thompson, Franz, \& Miller, 2009). Scholars have argued, and many teachers would agree, that improving teacherstudent relationships is an effective strategy to reduce discipline problems in the classroom (Jones, Jones, \& Vermette, 2013; Wolk, 2003). Taken together, this research supports the hypothesis that overall levels of disciplinary sanctions in a Montessori public school program may be lower than in traditional public schools.

It is unclear, however, whether an overall reduction in exclusionary discipline would also lead to more racially equitable use of disciplinary sanctions. Very little of the Montessori literature addresses racial dimensions of discipline. In her qualitative study of a public Montessori magnet program, Stansbury (2012) found evidence of both institutional racism and racially disparate disciplinary practices in the 
classroom. However, this study did not examine exclusionary sanctions like suspension, nor did it provide a comparison with a traditional school. While several studies have been conducted to compare academic achievement in Montessori and non-Montessori environments (Dohrmann et al., 2007; Lillard \& ElseQuest, 2006; Lopata, Wallace, \& Finn, 2005), there is a need for research on discipline outcomes in Montessori settings because discipline and achievement are inextricably linked (Gregory et al., 2010). Various studies have evaluated the academic benefits of Montessori for students of color (Ansari \& Winsler, 2014; Lopata et al., 2005; Rodriguez, Irby, Brown, Lara-Alecio, \& Galloway, 2005), but none have examined discipline for students of color in Montessori schools. This study aims to fill this gap and begin a conversation about discipline and equity in public school Montessori programs.

\section{Methodology}

\section{Sample}

This study focuses on three public Montessori elementary schools in a large urban district in the southeastern region of the United States and similar traditional elementary schools from within the same district. We sought a district in the South specifically because racially disproportionate discipline is more pronounced in this region (Wallace et al., 2008). We identified districts with public Montessori programs using a database constructed by sociologist Mira Debs, reflecting the directory publicly available from the National Center for Montessori in the Public Sector (NCMPS). Because available discipline data came from the 2011-2012 academic year, we eliminated from consideration schools that opened after this date from consideration. Districts that had three or more whole-school public Montessori programs at a single level (e.g., elementary) were eligible for the study. Montessori programs at the K-8 level were not considered due to the difficulty of selecting appropriate comparison schools. To be considered, public Montessori programs also had to have no less than 5\% Black and 5\% White students to calculate the Relative Rate Index (RRI). Only one district met these requirements. Because socioeconomic status has been found by some scholars to be related to exclusionary discipline (Cartledge et al., 2012), we included only schools with a comparable percentage of students qualifying for free or reduced lunch (FRL) in the comparison group. For the purposes of this analysis, traditional public schools were deemed socioeconomically comparable if their percentage of students qualifying for FRL was within $20 \%$ of the FRL rate for the three public Montessori schools. FRL rates are reported as part of the OCR Data Collection (U. S. Department of Education Office of Civil Rights, n.d.).

Table 1 contains basic demographic information for the schools included in the study. The Montessori schools and traditional schools are quite similar as a group, although the Montessori schools are smaller and, in aggregate, have both a larger proportion of Black students and a lower rate of students receiving free or reduced-price lunch than the traditional schools. The difference in size is not believed to be a confounding variable; although the literature indicates that school size is associated with increased discipline at the high school level, this association has been found to be weak or even nonexistent at the elementary level (North Carolina Department of Public Instruction, 2000). 
Table 1

Race, Socioeconomic Status, and Suspension Rates for Montessori and Traditional Schools

\begin{tabular}{|c|c|c|c|c|c|c|}
\hline \multirow[b]{2}{*}{ School } & \multicolumn{4}{|c|}{ Students } & \multirow{2}{*}{$\begin{array}{c}\text { Total No. } \\
\text { OSS }^{* *}\end{array}$} & \multirow{2}{*}{$\begin{array}{l}\text { OSS Rate } \\
\text { per Studen }\end{array}$} \\
\hline & Total No. & $\%$ Black & $\%$ White & $\% \mathrm{FRL}^{*}$ & & \\
\hline \multicolumn{7}{|l|}{ Montessori } \\
\hline M1 & 474 & 20.3 & 66.0 & 0 & 6 & .0127 \\
\hline M2 & 329 & 19.8 & 90.0 & 0 & 4 & .0122 \\
\hline M3 & 299 & 64.5 & 34.1 & 0 & 15 & .0502 \\
\hline Total & 1102 & 32.1 & 64.5 & 0 & 25 & .0227 \\
\hline \multicolumn{7}{|l|}{ Traditional } \\
\hline $\mathrm{T} 1$ & 974 & 11.50 & 73.7 & 19.7 & 4 & .0041 \\
\hline $\mathrm{T} 2$ & 813 & 12.70 & 60.6 & 0 & 12 & .0148 \\
\hline $\mathrm{T} 3$ & 675 & 17.50 & 69.0 & 0 & 0 & 0 \\
\hline $\mathrm{T} 4$ & 815 & 6.00 & 81.8 & 13.5 & 8 & .0010 \\
\hline T5 & 454 & 24.70 & 68.9 & 20.0 & 13 & .0286 \\
\hline T6 & 1012 & 7.20 & 74.5 & 11.5 & 30 & .0296 \\
\hline $\mathrm{T} 7$ & 987 & 8.90 & 61.8 & 8.3 & 8 & .0081 \\
\hline $\mathrm{T} 8$ & 878 & 10.00 & 69.5 & 13.0 & 35 & .0399 \\
\hline T9 & 1052 & 7.50 & 78.0 & 19.8 & 6 & .0057 \\
\hline $\mathrm{T} 10$ & 499 & 10.40 & 71.7 & 14.4 & 6 & .0120 \\
\hline $\mathrm{T} 11$ & 729 & 11.30 & 74.6 & 18.8 & 8 & .0110 \\
\hline $\mathrm{T} 12$ & 877 & 5.30 & 80.5 & 3.9 & 2 & .0023 \\
\hline $\mathrm{T} 13$ & 785 & 15.40 & 71.6 & 18.2 & 18 & .0229 \\
\hline $\mathrm{T} 14$ & 1234 & 9.10 & 78.6 & 13.1 & 10 & .0081 \\
\hline Total & 11784 & 10.50 & 72.9 & 12.4 & 160 & .0136 \\
\hline
\end{tabular}

Note. ${ }^{*}$ FRL $=$ Free and Reduced Lunch. ${ }^{* *}$ OSS = Out-of-School Suspension.

The average size of the three public Montessori schools is 367 students. These schools are magnet programs operated by the local school district; entrance is determined by lottery. All three schools report a $0 \%$ FRL rate. Two of these schools are predominantly White, while the third is predominantly Black; Black students make up 32\% of the total population of these three schools. All three schools serve students from kindergarten through sixth grade.

Using the criteria outlined above, we selected 14 traditional public schools as comparison schools. None of these schools offers a magnet program. On average, the FRL rate at these schools is $12.4 \%$. The average population of these schools is 842 students. All of these schools are predominantly White; Black students make up $10.5 \%$ of the combined population of these 14 schools. All 14 schools are elementary schools serving kindergarten through fifth grade; additionally, one school offers pre-K.

\section{Data Analysis}

The measure of discipline disproportionality employed for this study is the Relative Rate Index (RRI). This metric is endorsed by the Office of Juvenile Justice and Delinquency Prevention (Feyerherm, 
Snyder, \& Villarruel, 2009) as a measure of disproportionate minority contact with the criminal justice system. Essentially, the RRI is a ratio of the rate of criminal sanctions for non-Whites compared to the rate of criminal sanctions for Whites. An RRI of 1.0 indicates that the racial group in question is sanctioned at the same rate as Whites; an RRI of 2.0 would indicate that the minority group is sanctioned at a rate twice as high as the rate for Whites.

Tobin and Vincent (2011) provided a model of how the RRI can be applied to school discipline; the model, which was originally designed for use in criminal justice, is employed for analysis here. We calculated the rate of out-of-school suspension (OSS) for both Black and White students for each school by dividing the number of students from each group who were suspended out of school by the total number of students from that group. We multiplied this rate by 100 to find the suspension rate per 100 students for both Black and White students. We then divided the suspension rate for Black students by the suspension rates for White students to calculate the RRI for each school. Thus, the formula to calculate RRI is:

$$
\frac{(\text { No. of OSS for Black students } \div \text { Total no. of Black students }) \times 100}{(\text { No. of OSS for White students } \div \text { Total no. of White students }) \times 100}
$$

Because the sample size at each individual school was small, we calculated RRI for students at all three Montessori schools as a group and for students at all 14 comparison schools as a group to provide a large enough sample to conduct meaningful tests for statistical significance. Chi-square goodness-of-fit tests were conducted to test for statistical significance.

\section{Results}

Overall rates of suspension were not found to be different between the Montessori and traditional schools included in the sample. Table 1 includes the total number of OSS imposed at each school, as well as the overall rate of suspension, which was calculated by dividing total OSS by the population of the school. The chi-square test revealed no significant difference in observed frequency of OSS in Montessori schools and expected frequency of OSS in Montessori schools based on the rate of OSS in traditional schools, $\mathcal{X}^{2}(1, \mathrm{~N}=185)=2.224, p=.136$.

Table 2 indicates the numbers of Black and White students suspended at each school and for each group in aggregate. This table also displays the occurrence of OSS per 100 students for White and Black students, as well as each school's RRI. An RRI of 1.0 indicates that the occurrence of OSS is the same for both Black and White students; RRIs that are significantly greater or less than 1.0 indicate racial discipline disproportionality. Because the OSS rate for White students serves as the denominator when calculating the RRI, values could not be calculated for schools that had zero suspensions for White students. Conversely, if zero Black students were suspended, the RRI is 0 because the rate of OSS occurrence for Black students constitutes the numerator. RRIs for schools in the Montessori group ranged from 1.19 to 4.55, while RRIs in the traditional school group ranged from 0 to 13.77 .

To determine if the RRI was significantly different from 1.0, chi-square goodness-of-fit tests were conducted to compare the observed frequency of OSS for Black students with the expected frequency of OSS for Black students if they were suspended at the same rate as White students. One assumption of the chi-square test is that expected frequency must be greater than five; in all but one school, this assumption was violated. Thus, tests for statistical significance were not conducted at the individual school level. Instead, chi-square tests were conducted for all Montessori students as one group and for all traditional school students as another group. 
Table 2

Relative Rate Index (RRI) for Montessori and Traditional Schools

\begin{tabular}{|c|c|c|c|c|c|c|c|}
\hline School & $\begin{array}{l}\text { White } \\
\text { Student } \\
\text { OSS * }\end{array}$ & $\begin{array}{l}\text { Total No. } \\
\text { White } \\
\text { Students } \\
\end{array}$ & $\begin{array}{l}\text { OSS Rate } \\
\text { per } 100 \\
\text { White } \\
\text { Students } \\
\end{array}$ & $\begin{array}{c}\text { Black } \\
\text { Student } \\
\text { OSS } \\
\end{array}$ & $\begin{array}{c}\text { Total No. } \\
\text { Black } \\
\text { Students } \\
\end{array}$ & $\begin{array}{c}\text { OSS Rate } \\
\text { per } 100 \\
\text { Black } \\
\text { Students } \\
\end{array}$ & RRI \\
\hline \multicolumn{8}{|c|}{ Montessori } \\
\hline M1 & 4 & 313 & 1.28 & 2 & 96 & 2.08 & 1.63 \\
\hline M2 & 2 & 296 & 0.68 & 2 & 65 & 3.08 & 4.55 \\
\hline M3 & 4 & 102 & 3.92 & 9 & 193 & 4.66 & 1.19 \\
\hline Total & 10 & 711 & 1.41 & 13 & 354 & 3.67 & $2.61 * * *$ \\
\hline \multicolumn{8}{|l|}{ Traditional } \\
\hline $\mathrm{T} 1$ & 2 & 718 & 0.28 & 2 & 112 & 1.79 & 6.41 \\
\hline $\mathrm{T} 2$ & 4 & 493 & 0.81 & 4 & 103 & 3.88 & \multirow{2}{*}{$\begin{array}{l}4.78 \\
* *\end{array}$} \\
\hline $\mathrm{T} 3$ & 0 & 466 & 0 & 0 & 118 & 0 & \\
\hline $\mathrm{T} 4$ & 4 & 667 & 0.60 & 4 & 49 & 8.16 & 13.61 \\
\hline $\mathrm{T} 5$ & 4 & 313 & 1.28 & 9 & 112 & 8.04 & 6.29 \\
\hline T6 & 17 & 754 & 2.25 & 9 & 73 & 12.33 & 5.47 \\
\hline $\mathrm{T} 7$ & 2 & 610 & 0.33 & 2 & 88 & 2.27 & \multirow{2}{*}{$\begin{array}{l}6.93 \\
* * *\end{array}$} \\
\hline $\mathrm{T} 8$ & 0 & 610 & 0 & 35 & 88 & 39.77 & \\
\hline T9 & 2 & 821 & 0.24 & 0 & 79 & 0 & 0 \\
\hline $\mathrm{T} 10$ & 2 & 358 & 0.56 & 4 & 52 & 7.69 & 13.77 \\
\hline $\mathrm{T} 11$ & 4 & 544 & 0.74 & 4 & 82 & 4.88 & 6.63 \\
\hline $\mathrm{T} 12$ & 2 & 706 & 0.28 & 0 & 46 & 0 & 0 \\
\hline $\mathrm{T} 13$ & 6 & 562 & 1.07 & 8 & 121 & 6.61 & 6.19 \\
\hline $\mathrm{T} 14$ & 4 & 970 & 0.41 & 4 & 113 & 3.54 & 8.58 \\
\hline Total & 53 & 8592 & 0.62 & 85 & 1236 & 6.88 & $11.15^{* * *}$ \\
\hline
\end{tabular}

Note. ${ }^{*}$ OSS = Out-of-School Suspension; ${ }^{* *}=$ value could not be calculated.

*** $p<.001$

RRIs for both groups were found to be significantly different from 1.0, indicating the presence of racially disproportionate discipline in both settings. The RRI for the Montessori group was found to be significantly different from $1.0, \chi 2(1, \mathrm{~N}=354)=13.100, \mathrm{p}<.001$. For students in the Montessori group as a whole, the RRI was 2.61, indicating that Black students in Montessori schools were 2.61 times more likely to be suspended out of school than White students in these same Montessori schools. The RRI for the traditional schools was also found to be significantly different from $1.0, \chi 2(1, \mathrm{~N}=1236)=790.657$, $\mathrm{p}<.0001$. In the traditional school group in aggregate, the RRI was 11.15; Black students were 11.15 times more likely to receive OSS than their White peers. School T8, with 35 Black students suspended, could be considered an outlier; if this school is removed, the RRI for the traditional school group drops to 6.55 but is still significantly different from $1.0, \chi 2(1, \mathrm{~N}=1148)=261.802, p<.0001$, and substantially higher than the RRI for the Montessori group. The Montessori schools, as a group, are somewhat smaller than the traditional schools, but consistent with the literature, these data provide no indication that this difference is a confounding factor. Traditional schools T5 and T10 are both approximately the same size 
as the three Montessori schools, yet their RRIs are both substantially higher than the Montessori schools' and consistent with the other, larger, traditional schools.

\section{Discussion}

Rates of suspension were not found to be significantly different in Montessori and traditional schools. Although both Montessori and traditional schools in this study exhibited statistically significant levels of racially disproportionate discipline, this disproportionality was substantially more pronounced in the traditional schools. The first important implication of these findings is that the Montessori schools in this district are not immune to the phenomenon of racial discipline disproportionality. For the Montessori schools in this study, Black students were two to three times more likely than White students to be suspended out of school. This finding is consistent with previous studies of discipline disproportionality conducted in other school settings (Skiba et al., 2002; Wallace et al., 2008); in this regard, Montessori schools appear to be no better or worse than average. These data suggest, as some scholars have argued (Stansbury, 2012; Yezbick, 2007), that Montessori schools and teacher preparation programs have work to do in combating institutional racism and fostering cultural competency in teachers.

Second, although the Montessori schools in this study do exhibit racial discipline disproportionality, it appears to be less pronounced in Montessori settings than in comparable traditional schools in this district, despite having comparable levels of out-of-school suspensions. While Black students at Montessori schools are two to three times more likely to be suspended than their White classmates, Black students at the selected traditional schools are between six and seven times more likely to be suspended (if the more conservative figure is used). This is especially noteworthy because the Montessori schools have a larger proportion of Black students, and Skiba et al. (2015) found that discipline disproportionality exists at higher levels in schools with a larger proportion of students of color. Interestingly, while the rate of OSS for Black students in Montessori schools is lower than in traditional schools (3.67 students per 100 versus 6.88 students per 100, respectively), the rate of OSS for White students is over twice as high in Montessori schools than in traditional. Thus, the lower RRI in Montessori schools is a result of both lower rates of suspension for Black students and higher rates of suspension for White students. This finding merits further investigation.

\section{Limitations}

This study is constrained by several limitations that should be attended to when interpreting the findings. First, the Montessori schools in this study have a lower FRL population than the traditional schools selected for comparison. While efforts were made to select schools that were socioeconomically comparable, it was not possible to create a comparison group with an exactly equivalent FRL population. Skiba et al. (2015) argue that FRL percentage is not related to racially disparate discipline, so this difference may not be meaningful but must be acknowledged. Second, the Montessori programs in this district are choice programs; parents must actively elect to enroll their children in these programs instead of in their assigned elementary schools. Parents who choose Montessori for their children may be qualitatively different from other parents in a way that affects student behavior. Third, this study is only a snapshot of a single district in a single year. Further study is needed to determine if these findings can be replicated. Fourth, the Montessori schools, in aggregate, serve a higher proportion of Black students than the comparison schools. This disparity may be a confounding factor; again, further study is needed to isolate this variable. This study focuses only on suspension and does not address disciplinary actions leading up to suspension such as referrals or in-class behavioral interventions. Similarly, this study does not account for any special programs that may or may not have been in use in these schools such as PBIS or response to intervention. The infractions for which students were suspended were not considered. Future studies should include investigation of school and classroom-level disciplinary practices in Montessori settings. 


\section{Implications and Conclusion}

The findings of this study, limitations notwithstanding, have implications for both Montessori and mainstream educators. The finding of racially disproportionate disciplinary sanctions in Montessori settings suggests a need to better incorporate culturally responsive behavior-management techniques in Montessori teacher preparation programs and professional development. Although the Montessori Accreditation Council for Teacher Education (MACTE) does list "culturally responsive methods" as one of the required competencies for teacher candidates $(2015, \mathrm{p}$. 35), these findings indicate that teachers may be struggling to implement these methods. The teaching profession is overwhelmingly White (Hancock, 2011), and while data on the demographics of Montessori teachers are lacking, it is not unreasonable to assert that Montessori teachers are likely predominantly White also. While Whiteness is not necessarily a barrier to effectively teaching children of color, research indicates that White pre-service teachers are often unaware of their cultural biases and perspectives (Sleeter, 2008). Teachers and teacher candidates need opportunities to explore their cultural identities to develop cultural awareness (Miller \& Mikulec, 2014). This cultural awareness is key to reducing misinterpretations of culturally marked student behavior and communication (Banks et al., 2005) that can lead to disciplinary action.

While there is room for improvement in equitable discipline in the Montessori world, this study also suggests that Montessori may have something to offer traditional educators. Perhaps Montessori teachers come to know their students better over the three years they spend together, reducing the likelihood that the behavior of students of color will be misinterpreted. The highly individualized format of the Montessori classroom may also provide Montessori teachers with the time and space to develop this deep knowledge, mutual respect, and trust with their students of color. The hands-on, collaborative nature of Montessori education may be more engaging for students of color. The freedom that Montessori students have to move and talk may allow students of color to engage in behaviors for which they would be disproportionately censured in a traditional setting. Further study of how Montessori teachers interact with and discipline their students of color is needed to determine if these conjectures have any basis in reality. As students of color continue to make up a growing proportion of the American public school population, questions like these will be of even greater importance if Montessori is to be the force for peace and justice that its creator always intended.

\section{AUTHOR INFORMATION}

\section{+Corresponding Author}

Katie E. Brown $\uparrow$ is a $\mathrm{PhD}$ student in the Curriculum and Instruction Program at the University of North Carolina at Charlotte, with a focus on urban education. She can be reached at kgolfus@uncc.edu.

Aimy S.L. Steele is a PhD student in the Curriculum and Instruction Program at the University of North Carolina at Charlotte, with a focus on urban education.

\section{References}

American Civil Liberties Union. (n.d.). School-to-prison pipeline. Retrieved from https://www.aclu.org/school-prison-pipeline

American Psychological Association Zero Tolerance Task Force. (2008). Are zero tolerance policies effective in the schools? An evidentiary review and recommendations. The American Psychologist, 63(9), 852. doi: 10.1037/0003-066X.63.9.852

Ansari, A., \& Winsler, A. (2014). Montessori public school pre-K programs and the school readiness of low-income Black and Latino children. Journal of Educational Psychology, 106(4), 1066-1079.

Banks, J., Cochran-Smith, M., Moll, L., Richert, A., Zeichner, K., LePage, P., Darling-Hammond, L., \& Duffy, H., (with McDonald, M). (2005). Teaching diverse learners. In L. Darling-Hammond \& J. Bransford (Eds.), Preparing teachers for a changing world: What teachers should learn and be able to do (pp. 232-274). San Francisco, CA: Jossey-Bass. 
Bradshaw, C. P., Mitchell, M. M., O’Brennan, L. M., \& Leaf, P. J. (2010). Multilevel exploration of factors contributing to the overrepresentation of black students in office disciplinary referrals. Journal of Educational Psychology, 102(2), 508-520. doi: 10.1037/a0018450

Butler, B. R., Lewis, C. W., Moore, J. L., III, \& Scott, M. E. (2012). Assessing the odds: Disproportional discipline practices and implications for educational stakeholders. The Journal of Negro Education, 81(1), 11-24.

Byun, W., Blair, S. N., \& Pate, R. R. (2013). Objectively measured sedentary behavior in preschool children: Comparison between Montessori and traditional preschools. International Journal of Behavioral Nutrition and Physical Activity, 10(2), 1-7. Retrieved from http://www.biomedcentral.com/content/pdf/1479-5868-10-2.pdf

Cartledge, G., Gibson, L., Jr., \& Keyes, S.E. (2012). Special education and disciplinary disproportionality of African American students. In J. L. Moore III \& C. W. Lewis (Eds.), African American students in urban schools (pp. 75-93). New York, NY: Peter Lang.

Castellanos, A. G. (2002). A comparison of traditional vs. Montessori education in relation to children's self-esteem, self-efficacy, and prosocial behavior (Doctoral dissertation). Retrieved from UMI (3070508).

Children's Defense Fund. (1975). Out-of-school suspensions: Are they helping children? Cambridge, MA: Children's Defense Fund.

Children's Defense Fund of Ohio. (2012). Zero tolerance and exclusionary school discipline policies harm students and contribute to the cradle to prison pipeline. Retrieved from http://www.cdfohio.org/assets/pdf-files/issue-brief-zero-tolerance.pdf

Christle, C. A., Jolivette, K., Nelson, C. M. (2005). Breaking the school to prison pipeline: Identifying school risk and protective factors for youth delinquency. Exceptionality, 13(2), 69-88. doi: $10.1207 / \mathrm{s} 15327035 \mathrm{ex} 1302 \_2$

Cornell, D., \& Lovegrove, P. (2015). Student threat assessment as a method of reducing student suspensions. In D. J. Losen (Ed.), Closing the school discipline gap: Equitable remedies for excessive exclusion (pp. 180-191). New York, NY: Teachers College Press.

Dohrmann, K. R., Nishida, T. K., Gartner, A., Lipsky, D. K., \& Grimm, K. J. (2007). High school outcomes for students in a public Montessori program. Journal of Research in Childhood Education, 22(2), 205-217. doi: 10.1080/02568540709594622

Ervin, B., Wash, P. D., \& Mecca, M. E. (2010). A 3-year study of self-regulation in Montessori and nonMontessori classrooms. Montessori Life, 2010, 22(2), 22-31.

Feyerherm, W., Snyder, H. N., \& Villarruel, F. (2009). Chapter 1: Identification and monitoring. In Disproportionate Minority Contact (DMC) Technical Assistance Manual (4th ed.) (pp. 1-1-1-54). Washington, DC: U.S. Department of Justice Office of Justice Programs.

Flores, A. (2007). Examining disparities in mathematics education: Achievement gap or opportunity gap? The High School Journal, 91(1), 29-42.

Gonzalez, T. (2015). Socializing schools: Addressing racial disparities in discipline through restorative justice. In D. J. Losen (Ed.), Closing the school discipline gap: Equitable remedies for excessive exclusion (pp. 151-165). New York, NY: Teachers College Press.

Gregory, A., Skiba, R. J., \& Noguera, P. A. (2010). The achievement gap and the discipline gap: Two sides of the same coin? Educational Researcher, 39(1), 59-68. doi: 10.3102/0013189X09357621

Hancock, S. D. (2011). White women's work: On the front lines of urban education. In J. G. Landsman \& C. W. Lewis (Eds.), White teachers / diverse classrooms: Creating inclusive schools, building on students' diversity, and providing true educational equity (2nd ed., pp. 93-109). Sterling, VA: Stylus.

Hirschfield, P. J. (2010). School surveillance in America: Disparate and unequal. In T. Monahan \& R. Torres (Eds.), Schools under surveillance: Cultures of control in public education (pp. 38-54). New Brunswick, NH: Rutgers University Press. 
James, M. (2014, November). Keeping our promises: Exposing and subverting educational inequities in urban schools in the 21st century. Paper presented at the 1st Biennial International Conference on Urban Education, Montego Bay, Jamaica.

Johnson, T., Boyden, J. E., \& Pittz, W. J. (2001). Racial profiling and punishment in U.S. public schools: How zero tolerance policies and high stakes testing subvert academic excellence and racial equity. Research report [and] executive summary. Oakland, CA: Applied Research Center.

Jones, K. A., Jones, J. L., \& Vermette, P. J. (2013). Exploring the complexity of classroom management: 8 components of managing a highly productive, safe, and respectful urban environment. American Secondary Education, 41(3), 21-33.

Kaufman, J. S., Jaser, S. S., Vaughan, E. L., Reynolds, J. S., Di Donato, J., Bernard, S. N., \& HernandezBrereton, M. (2010). Patterns in office referral data by grade, race/ethnicity, and gender. Journal of Positive Behavior Interventions, 12(1), 44-54. doi: 10.1177/1098300708329710

KewalRamani, A., Gilbertson, L., Fox, M. A., \& Provasnik, S. (2007). Status and trends in the education of racial and ethnic minorities (NCES 2007-039). Washington, DC: National Center for Education Statistics, Institute of Education Sciences, U.S. Department of Education.

Klem, A. M., \& Connell, J. P. (2004). Relationships matter: Linking teacher support to student engagement and achievement. Journal of School Health, 74(7), 262-273. doi: 10.1111/j.17461561.2004.tb08283.x

Krezmien, M. P., Leone, P. E., \& Achilles, G. M. (2006). Suspension, race, and disability: Analysis of statewide practices and reporting. Journal of Emotional and Behavioral Disorders, 14(4), $217-$ 226. doi: $10.1177 / 10634266060140040501$

Lee, J. (2002). Racial and ethnic achievement gap trends: Reversing the progress toward equity? Educational Researcher, 31(1), 3-12. doi: 10.3102/0013189X031001003

Lee, J., Grigg, W., \& Donahue, P. (2007). The nation's report card: Reading 2007 (NCES 2007-496). Washington, DC: National Center for Education Statistics, Institute of Education Sciences, U. S. Department of Education.

Lewis, C. W., Butler, B. R., Bonner, F. A., III, \& Joubert, M. (2010). African American male discipline patterns and school district responses resulting impact on academic achievement: Implications for urban educators and policy makers. Journal of African American Males in Education, 1(1), 7-25.

Lewis, C. W., Chambers, T. V., \& Butler, B. R. (2012). Urban education in the 21 st century: An overview of selected issues that impact African American student outcomes. In J. L. Moore \& C. W. Lewis (Eds.), African American students in urban schools: Critical issues and solutions for achievement (pp. 11-30). New York, NY: Peter Lang.

Lindsay, L. A., Irving, M. A., Tanner, T., \& Underdue, D. (2008). In the loop: An examination of the effectiveness of looping for African American students. Curriculum and Research, 1(4), 150-162.

Lillard, A. S. (2005). Montessori: The science behind the genius. New York, NY: Oxford University Press.

Lillard, A. S., \& Else-Quest, N. (2006). Evaluating Montessori education. Science, 313(5795), 1893-1894. doi: $10.1126 /$ science. 1132362

Lopata, C., Wallace, N. V., \& Finn, K. V. (2005). Comparison of academic achievement between Montessori and traditional education programs. Journal of Research in Childhood Education, 20(1), 5-13.

Miller, P. C., \& Mikulec, E. A. (2014). Pre-service teachers confronting issues of diversity through a radical field experience. Multicultural Education, 21(2), 18-24.

Montessori Accreditation Council for Teacher Education (MACTE). (2015). 2015 guide to accreditation. Retrieved from http://www.macte.org/wp-content/uploads/2015/05/MACTE-Guide-toAccreditation-2015.pdf

North Carolina Department of Public Instruction (NCDPI). (2000). School size and its relationship to achievement and behavior Retrieved from NCDPI: http://www.ncpublicschools.org/docs/data/reports/size.pdf 
Rathunde, K., \& Csikszentmihalyi, M. (2005). Middle school students' motivation and quality of experience: A comparison of Montessori and traditional school environments. American Journal of Education, 111(3), 341-371.

Rodriguez, L., Irby, B. J., Brown, G., Lara-Alecio, R., \& Galloway, M. M. (2005). An analysis of reading achievement related to pre-kindergarten Montessori and transitional bilingual education. In V. Gonzalez \& J. Tinajero (Eds.), Review of Research and Practice (Vol 3., pp. 45-65). Mahwah, NJ: Erlbaum.

Shollenberger, T. L. (2015). Racial disparities in school suspension and subsequent outcomes: Evidence from the National Longitudinal Survey of Youth. In D. J. Losen (Ed.), Closing the school discipline gap: Equitable remedies for excessive exclusion (pp. 31-43). New York, NY: Teachers College Press.

Skiba, R. J. (2005). Minority disproportionality in special education and school discipline: What we know, what we need to know [PowerPoint slides]. Retrieved from http://www.urbancollaborative.org/pdfs/Fall05/Skiba.pdf

Skiba, R. J., Chung, C.-G., Trachok, M., Baker, T., Sheya, A., \& Hughes, R. (2015). Where should we intervene? Contributions of behavior, student, and school characteristics to out-of-school suspension. In D. J. Losen (Ed.), Closing the school discipline gap: Equitable remedies for excessive exclusion (pp. 132-146). New York, NY: Teachers College Press.

Skiba, R. J., Horner, R. H., Chung, C.-G., Rausch, M. K., May, S. L., \& Tobin, T. J. (2011). Race is not neutral: A national investigation of African American and Latino disproportionality in school discipline. School Psychology Review, 40(1), 85-107.

Skiba, R. J., Michael, R. S., Nardo, A. C., \& Peterson, R. L. (2002). The color of discipline: Sources of racial and gender disproportionality in school punishment. Urban Review, 34(4), 317-342.

Skiba, R. J., Peterson, R. L., \& Williams, T. (1997). Office referrals and suspension: Disciplinary intervention in middle schools. Education \& Treatment of Children, 20(3), 295-315.

Skiba, R. J., \& Rausch, M. K. (2006). Zero tolerance, suspension, and expulsion: Questions of equity and effectiveness. In C. M. Evertson \& C. S. Weinstein (Eds.), Handbook of classroom management: Research, practice, and contemporary issues (pp. 1063-1089). Mahwah, NJ: Erlbaum.

Sleeter, C. E. (2008). Preparing White teachers for diverse students. In M. Cochran-Smith, S. FeimanNemser, \& D. J. McIntyre, (Eds.), Handbook of research on teacher education: Enduring questions in changing contexts (3rd ed., pp. 559-582). New York, NY: Routledge.

Stansbury, J. (2012). Dealing with diversity: Administrator, teacher and parent perceptions of the responsiveness of Montessori schools to racial and ethnic diversity (Unpublished master's thesis). DePaul University, Chicago, IL.

Thompson, N. L., Franz, D. P., \& Miller, N. (2009). Research summary: Looping. Retrieved from National Middle School Association/Association for Middle Level Education http://www.amle.org/TabId/198/ArtMID/696/ArticleID/311/Research-Summary-Looping.aspx.

Tobin, T. J., \& Vincent, C. G. (2011). Strategies for preventing disproportionate exclusions of African American students. Preventing School Failure: Alternative Education for Children and Youth, 55(4), 192-201. doi: 10.1080/1045988X.2010.532520

U. S. Department of Education Office of Civil Rights (n.d.). Civil rights data collection. Retrieved from http://ocrdata.ed.gov/DistrictSchoolSearch?ds=1\#schoolSearch

U. S. Department of Education Office of Civil Rights. (2014). Civil rights data collection snapshot: School discipline. (Issue Brief No. 1). Retrieved from https://www2.ed.gov/about/offices/list/ocr/docs/crdc-discipline-snapshot.pdf

Vincent, C. G., Sprague, J. R., Pavel, M., Tobin, T. J., \& Gau, J. M. (2015). Effectiveness of schoolwide positive behavior interventions and supports in reducing racially inequitable disciplinary exclusion. In D. J. Losen (Ed.), Closing the school discipline gap: Equitable remedies for excessive exclusion (pp. 207-221). New York, NY: Teachers College Press. 
Vincent, C. G., Swain-Bradway, J., Tobin, T. J., \& May, S. (2011). Disciplinary referrals or culturally and linguistically diverse students with and without disabilities: Patterns resulting from school-wide positive behavior support. Exceptionality, 19(3), 175-190. doi: 10.1080/09362835.2011.579936

Vincent, C. G., Tobin, T. J., Hawken, L. S., \& Frank, J. L. (2012). Discipline referrals and access to secondary level support in elementary and middle schools: Patterns across African-American, Hispanic-American, and White students. Education and Treatment of Children, 35(3), 431-458. doi: $10.1353 /$ etc. 2012.0018

Wacquant, L. (2000). Deadly symbiosis: When ghetto and prison meet and mesh. Punishment and Society, 3(1), 95-133. doi: $10.1177 / 14624740122228276$

Wald, J., \& Losen, D. J. (2003). Defining and redirecting a school-to-prison pipeline. In J. Wald \& D. J. Losen (Eds.), New directions for youth development: Vol. 99. Deconstructing the school-to-prison pipeline (pp. 9-15). San Francisco, CA: Jossey-Bass.

Wallace, J. M., Jr., Goodkind, S., Wallace, C. M., \& Bachman, J. G. (2008). Racial, ethnic, and gender differences in school discipline among US high school students: 1991-2005. The Negro Educational Review, 59(1-2), 47.

Weinstein, C., Curran, M., \& Tomlinson-Clarke, S. (2003). Culturally responsive classroom management: Awareness into action. Theory Into Practice, 42(4), 269-276.

Wolk, S. (2003). Hearts and minds. Educational Leadership, 61(1), 14-18.

Yezbick, M. (2007). How Montessori educators in the U.S. address culturally responsive teaching. (Unpublished master's thesis). San Francisco State University: San Francisco, CA. 